\title{
Proper Handwashing for Produce Handlers ${ }^{1}$
}

\author{
Amy Simonne, Mark Ritenour, Jeff Brecht, Steve Sargent and Keith Schneider ${ }^{2}$
}
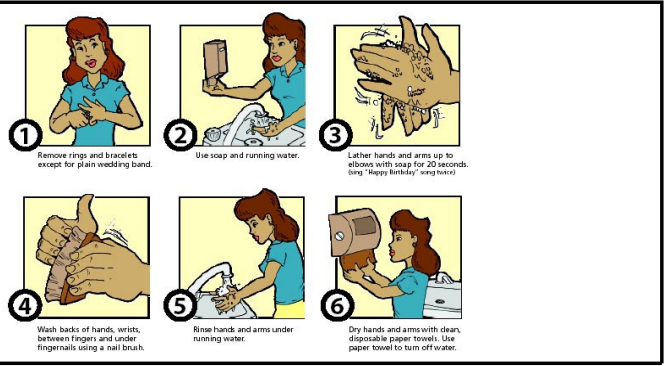

Figure 1.

Wash your hands before:

- returning to the field or entering the packing line

- touching clean produce

- putting on new gloves

- preparing food

- consuming food

Wash your hands after:
- visiting the restroom

- touching bare human body parts (ear, nose, hair, etc.)

- working with soil or rotten produce

- handling garbage

- smoking or doing other activities that dirty your hands

1. This document is FCS8762-Eng, one of a series of the Department of Family, Youth and Community Sciences, Florida Cooperative Extension Service, IFAS, University of Florida, Gainesville FL 32611. First published: March 2004. Reviewed by Linda B. Bobroff, Ph.D., RD, LD/N, Family, Youth and Community Sciences. Meredith C. Taylor, M.S., FCS, P.L., extension agent IV, Suwannee County. Sally K. Williams, Ph.D., associate professor, Animal Sciences. Institute of Food and Agricultural Sciences, University of Florida, Gainesville, FL 32611. Please visit the EDIS Web site at http://edis.ifas.ufl.edu

2. Amy Simonne, Ph.D., assistant professor, Department of Family, Youth and Community Sciences; Mark Ritenour, Ph.D., assistant professor, Indian River REC; Jeff Brecht, Ph.D., professor and Steve Sargent, Ph.D., professor, Horticultural Sciences Department; and Keith Schneider, Ph.D., assistant professor, Department of Food Science \& Human Nutrition. Cooperative Extension Service, Institute of Food and Agricultural Sciences, University of Florida, Gainesville, FL 32611.

The Institute of Food and Agricultural Sciences (IFAS) is an Equal Employment Opportunity - Affirmative Action Employer authorized to provide research, educational information and other services only to individuals and institutions that function without regard to race, creed, color, religion, age, disability, sex, sexual orientation, marital status, national origin, political opinions or affiliations. For information on obtaining other extension publications, contact your county Cooperative Extension Service office. Florida Cooperative Extension Service / Institute of Food and Agricultural Sciences / University of Florida / Larry R. Arrington, Interim Dean 